\title{
Hva er et navn?
}

\author{
What's in a name? That which we \\ call a rose \\ By any other name would smell as \\ sweet (1)
}

Da vi for noen år siden flyttet til Danmark for en stund, opplevet jeg at folk plutselig kalte min sønn mongoloid og et mongolbarn. Det var interessant. Interessant fordi mongoloid er et ord min generasjon kjenner fra barndommen. Mongoloide gikk ikke på vår skole. Ja, så merkelige var de at de ikke engang kunne bo hjemme, men bodde på spesielle institusjoner, nærmest sykehus. Hele livet. Vi så vel ned på dem, antar jeg. Egentlig. Det var et slikt barn jeg trodde jeg skulle få. Men så viste det seg jo etter hvert at det ikke var et slikt barn. Annerledes, ja visst, men på en annen måte. En av oss, definitivt. Så da vi senere flyttet til Danmark og man snakket til meg om at jeg hadde et mongolbarn, måtte jeg jo rett og slett protestere. Jeg måtte forklare dem at hos oss, der i nord, gikk barna på vanlig skole. Vanlig barnehave. De ble ikke regelmessig screenet etter i mors liv i alle fall ikke så regelmessig som i Danmark, kort sagt, de kunne gjerne ha mongolbarn for min skyld i Danmark, men i Norge hadde vi sluttet med mongolbarn, og i alle fall hos meg fantes det ikke slikt. Ikke min sønn. Kanskje har han Downs syndrom, det kan jeg vel kanskje gå med på, men det er ikke helt sikkert, det heller. Jeg har nemlig i den senere tid kommet frem til at det også kommer litt an på hvem som spør. Og hvorfor.

Sosiale frigjøringsgrupper, antirasister, feminister tar gjerne fatt i de betegnelser som brukes om dem - utenfraspråket erobrer det og tilraner seg makten til å definere ordene. Man prøver å snu det fra et utenfraperspektiv - snakke om - til et innenfraperspektiv - snakke som. Snakke som farget, snakke som kvinne, snakke som - annerledes? Dersom man har Downs syndrom, for eksempel, og skulle begynne å definere hva det er - for seg selv - hvordan ville man da gripe saken an? Hva er Downs syndrom i et slikt perspektiv?

Noen mener det er viktig med diagnosebevissthet. At unge mennesker som vi oppfatter som annerledes på grunn av en diagnose, har godt av å kunne snakke om den diagnosen. Kanskje det. Eller kanskje ikke. Det kan jo bare være nyttig å tilføre en slik bevissthet dersom Downs syndrom, eller hvilken diagnose det nå er, har en mening for meg - for den det gjelder. Ordet er jo ikke intuitivt forståelig, selv om enkelte svake sjeler som bruker det som skjellsord tror det. Er Downs syndrom en identitet? Bør det være det? Eller er det et ord utenfra, en definisjon som vi tvinger folk inn i - fordi vi mener det er viktig?

Er det viktig å forstå at man er annerledes? Er man annerledes om man ikke synes det selv? Hvilket perspektiv er viktig her?

Om jeg skulle spørre min sønn hvem han er, ville han svare at han er en ung mann med Downs syndrom? Neppe. Det gir ikke mening. Han er norsk, han har et navn, en familie, han liker det han liker og er venn med sine venner. Han er den han er.

Hva hører du når du hører Downs syndrom? En som er litt marginalisert? Min sønn mener ikke han er marginalisert - han er midt i sitt eget liv og ikke på siden. En som man kan se ned på? Definitivt ikke. En som ser annerledes ut? Nei, egentlig ikke, han legger vekt på å være en litt stilig kar. Men en ting han er litt opptatt av er plagen ved ikke å kunne si r. Derfor mener han at han har r-sykdom. En venn i som vi voksne nok mener har Downs syndrom, har imidlertid en aldeles utmerket r. Så de har slett ikke samme sykdom. Én kan si r og én kan ikke - det er det som teller. Og slutt å spørre så dumt.

Har han virkelig Downs syndrom - hva mener jeg? Ja, om det er et ord med respekt, går jeg med på det. Om det er for å fremskaffe omtanke og omsorg, går jeg med på det. Men det er en del grums som har samlet seg i uttrykket. Diagnosen blir brukt også til andre ting. Som unnskyldning for tilsidesetting, som årsak til diskriminering.

Som mor er det nok derfor min plikt å gjøre oppmerksom på at svaret på spørsmålet helt og holdent avhenger av hvem som spør og hvorfor.

\section{Litteratur}

1. Gibbons B, red. Romeo and Juliet. The Arden Shakespeare Second Series. London: Thomson Learning, 1980: II, ii, 1-2. 